\title{
The Use of Realistic Mathematics Education (RME) in Improving Mathematical Analogical Ability and Habits of Mind
}

\author{
Farida $^{1}$, Hartatiana ${ }^{2}$, Watcharin Joemsittiprasert ${ }^{3}$ \\ 1, Universitas Islam Negeri Raden Intan Lampung \\ ${ }^{2}$ Universitas Islam Negeri Raden Fatah Palembang \\ ${ }^{3}$ Division of Business Administration, ASA College, New York, USA \\ ${ }^{1}$ Correspondence Address; farida@radenintan.ac.id
}

\begin{abstract}
The purposesof this study are to see whether there are differences in mathematical analogical abilities between the class that was taught using Realistic Mathematics Education (RME) and class that was taught using expository learning, to see whether there are differences in mathematical analogical abilities of students who have high, medium, low habits of mind taught using Realistic Mathematics Education Learning (RME), and to see whether there is an interaction between the use of Realistic Mathematics Education Learning (RME) on habits of mindand students' mathematical analogical abilities. This research is experimental, specifically thequasiexperimental design. The two-way ANOVA was used to analyze the data. Based on the results of the study, it can be concluded that: 1) there are differences in mathematical analogical abilities between the class that was taught using Realistic Mathematics Education (RME) and class that was taught using expository learning; 2) there are differences in mathematical analogical abilities of students who have high, medium, lowhabits of mind taught using Realistic Mathematics Education Learning (RME); 3) there is no interaction between the use of Realistic Mathematics Education Learning (RME)on the habits of mind and students' mathematical analogical abilities. Keywords: Realistic Mathematics Education (RME), Habits of Mind, Mathematical Analogical Ability
\end{abstract}

\section{INTRODUCTION}

A learning process should be related to daily life. The process of learning mathematics taught by linking the real-life is better known as contextual mathematics learning that can help the teachers link the learning material with the real-world situations and can encourage students to make connections between the knowledge they possess and its application in their lives as a family and community members (Trianto, 2008). One of the contextual learning in mathematics learning that is often applied is Realistic Mathematics Education (RME). The Realistic Mathematics Education (RME) approach that takes into account the local conditions (culture, environment, or context) shows that students are no longer afraid to express their ideas, dare to provide different problem solving with their peers, and grow their creativity in solving a problem collaboratively (Fernandes, Farida, Fitria, Fauzan, \& Nelvyarni, 2018; Fitriani, Suryadi, \& Darhim, 2018; Susanti \& Rustam, 2018). The determinants of mathematics learning outcomes are analogical skills and attitude or affective factors. The analogical ability is closely related to mathematics. Mathematical analytical skills need to be a focus of attention in learning mathematics because through logic, the students can develop mathematical thinking abilities and they can understand mathematical ideas that are interrelated with one another. The habit of giving arguments to the answer and giving responses to other people's answers will make learning mathematics more meaningful.

The role of analogous mathematics is very important in mathematics learning. The mathematical analogy is needed by students to provide conclusions about ideas or problem 
solving between mathematical concepts. Learning activities that are still dominated by learning to make the students able to solve rational ideas about a statement are deemed inappropriate. Besides, the mathematical analogical abilities in the learning process also need to be studied of their affective factors. The dominant effective factor in the learning process is habitual thinking which is often known as habits of mind (Nurjannah, Hendriana, \& Fitrianna, 2018; Safitri, 2017). In situations where an individual does not know how to respond to a problem, it is necessary to behave intelligently to overcome it in the sense of not only knowing the information but also knowing how to act. The ability to behave intelligently is referred to as habits of mind(Sriyati, 2010).

Several previous studies have discussed how RME influences learning (Atika \& Mz, 2016; Dolk \& Eerde, 2013; Hidayat \& Iksan, 2015; Rudiono, Dafik, \& Wahyuningrum, 2015), research in improving mathematical analogical abilities (Azmi, 2017; Rahman \& Maarif, 2014), and research examining habits of mind (HOM). (Bidari, 2016; Indriani, 2018; Masni, 2017; Miliyawati, 2017; Nahadi, H, \& Farina, 2015; Nurmaulita, 2014; Sriyati, Rustaman, \& Zainul, 2010; Zhok, 2016). However, there has been no research that investigates the effect of RME learning in improving mathematical analogical abilities and habits of mind (HOM). Based on previous research, the renewal of this study is focused on the effect of RME learning in improving mathematical analogical abilities and habits of mind (HOM). Thus, the purpose of this study is to see whether there are differences in mathematical analogical abilities between the class that was taught using Realistic Mathematics Education (RME) and class that was taught using expository learning, to see whether there are differences in mathematical analogical abilities of students who have high, medium, low habits of mind taught using Realistic Mathematics Education Learning (RME), and to see whether there is an interaction between the use of Realistic Mathematics Education Learning (RME) on habits of mind and students' mathematical analogical abilities.

\section{THE RESEARCH METHODS}

The type of research employed is the experimental research with a quasi-experimental design that has a control group but does not function fully to control external variables that affect the implementation of the experiment (Sugiyono, 2013). The population in this study were all mathematics education students who took the Real Analysis Course 1. The sampling technique used was the class random technique. The instruments used in this study were test instruments (mathematical analogical thinking ability tests) and questionnaire instruments (questionnaire on habits of Mind). The data was then analyzed using two-way ANOVA with the prerequisite tests of normality and homogeneity tests.

\section{THE RESULTS OF THE RESEARCH AND THE DISCUSSION}

The results of the research were obtained by testing the data using the ANOVA test, but before the ANOVA test was carried out, the normality and homogeneity tests were used as a prerequisite test. 
Table 1. The Normality Test of Mathematical Analogical Abilitiesin the Experimental and Control Classes

\begin{tabular}{ccccc}
\hline Classes & Lobserved & LCritical & Index & Interpretation \\
\hline Experimental & 0.1069 & 0.1726 & $\mathrm{~L}_{\mathrm{h}} \leq \mathrm{L}_{\mathrm{t}}$ & Normal \\
Control & 0.0938 & 0.1726 & $\mathrm{~L}_{\mathrm{h}} \leq \mathrm{L}_{\mathrm{t}}$ & Normal \\
\hline
\end{tabular}

Based on Table 1, it can be seen that both the experimental class and the control class were normally distributed because $\mathrm{L}_{0} \leq \mathrm{L}_{c}$, so, the homogeneity test could be carried out as can be seen in Table 2.

Table 2. The Homogeneity Test of Mathematical Analogical Abilities

\begin{tabular}{lccc}
\multicolumn{1}{c}{ Test Data } & $\chi^{2}$ observed & $\chi^{2}$ critical & Interpretation \\
$\begin{array}{l}\text { The Mathematical } \\
\begin{array}{l}\text { AnalogicalAbilities of the Control } \\
\text { and Experimental Classes }\end{array}\end{array}$ & 0.0830 & 3.841 & Homogeneous \\
& & & \\
\hline
\end{tabular}

Table 2, the homogeneity test used in this study was the homogeneity test of the experimental class and control class. It was obtained that the $\boldsymbol{\chi}^{\mathbf{2}}$ critical was 0.0830 and $\boldsymbol{\chi}^{\mathbf{2}}$ observed was 3.841 with a significance level of 0.05 and degrees of freedom of 1 . Based on the results of the calculations, $\chi^{2}$ observed $<\chi^{2}$ critical so that $\mathrm{H}_{0}$ is accepted. It means that both samples came from the same population (homogeneous). After the prerequisite tests had been done, the analysis can be continued testing the research hypothesis using the two-way ANAVA with Unequal Cells.

The research hypotheses were tested to see the differences in mathematical analogical abilities between the class that was taught using Realistic Mathematics Education (RME) and class that was taught using expository learning, to see whether there are differences in mathematical analogical abilities of students who have high, medium, low habits of mind taught using Realistic Mathematics Education Learning (RME), and to see whether there is an interaction between the use of Realistic Mathematics Education Learning (RME) on habits of mindand students' mathematical analogical abilities. The summary of ANAVA calculation results are presented in Table 3:

Table 3. The Summary of Two-Way ANAVA with Unequal Cells

\begin{tabular}{cccccc}
\hline Source & JK & Dk & RK & Fobserved & F critical \\
\hline Learning(A) & 11,226 & 1 & 11,226 & 9,953 & 4,073 \\
Habits of Mind (B) & 288,307 & 2 & 144,153 & 127,808 & 3,220 \\
Interactions (A) & 0.231 & 2 & 0.115 & 0.102 & 3.220 \\
errors, & 47.371 & 42 & 128 & - & - \\
Total & 347.135 & 47 & - & - & - \\
\hline
\end{tabular}

Based on Table 3, it can be seen that $\mathrm{H}_{0 \mathrm{~A}}$ is rejected, $\mathrm{H}_{0 \mathrm{~B}}$ is rejected, and $\mathrm{H}_{0 \mathrm{AB}}$ is rejected with the following assumptions:

a. $F_{a}$ observed $=9.953$ and $F_{a}$ critical $=4,073$. Based on the calculation of data analysis in the table, it can be seen that $\left\{\mathrm{F}_{\text {observed }}>4,073\right\}$. Thus, it can be concluded that $\mathrm{H}_{0 \mathrm{a}}$ is rejected, with 
the research hypothesis $\mathrm{H}_{0 \mathrm{~A}}: \alpha_{i}=0$. There is no difference in mathematical analogical abilities of students between the class that was taught using Realistic Mathematics Education (RME) and class that was taught using expository learning. $\mathrm{H}_{1 \mathrm{~A}}: \alpha_{i} \neq 0$, there are differences in mathematical analogical abilities between the class that was taught using Realistic Mathematics Education (RME) and class that was taught using expository learning. This means that there are differences in mathematical analogical abilities between the class that was taught using Realistic Mathematics Education (RME) and class that was taught using expository learning.

b. $F_{b}$ observed $=127.808$ and $F_{b}$ critical $=3.220$. Based on the calculation of data analysis in the table, it can be seen that $\left\{\mathrm{F}_{\mathrm{b} \text { observed }}>3,220\right\}$. Thus, it can be concluded that $\mathrm{H}_{0 \mathrm{~b}}$ is rejected with the research hypothesis $\mathrm{H}_{0 \mathrm{~B}}: \beta_{\mathrm{j}}=0$. There is no difference in mathematical analogical abilities of students who have high, medium, low habits of mind taught using Realistic Mathematics Education Learning (RME). $\mathrm{H}_{1 \mathrm{~B}}: \beta_{\mathrm{j}} \neq 0$ There are differences in mathematical analogical abilities of students who have high, medium, low habits of mind taught using Realistic Mathematics Education Learning(RME). This means that there are differences in students' mathematical analogical abilities of students who have high, medium, low habits of mind taught using Realistic Mathematics Education Learning (RME).

c. $F_{\text {observed }}=0.102$ and $F_{\text {critical }}=3.220$. Based on the calculation of data analysis in the table, it can be seen that $\left\{\mathrm{F}_{\mathrm{ab} \text { observed }}<3,220\right\}$. Thus, it can be concluded that $\mathrm{H}_{0 \mathrm{AB}}$ is accepted with the hypothesis of $\mathrm{H}_{0 \mathrm{AB}}:(\alpha \beta)_{\mathrm{ij}}=0$. There is no interaction between the use of Realistic Mathematics Education Learning (RME) and expository learning toward students' analogical mathematical ability and habits ofmind. $\mathrm{H}_{1 \mathrm{AB}}:(\alpha \beta)_{\mathrm{ij}} \neq 0$, There is an interaction between the use of Realistic Mathematics Education Learning (RME) and expository learning toward students' analogical mathematical ability and habits of mind. This means that there is an interaction between the use of Realistic Mathematics Education Learning (RME) on habits of mindand students' mathematical analogical abilities.

The data of this study was obtained through tests, questionnaires, and documentation. Researchers used two classes in this study namely class $\mathrm{C}$ as the experimental class and class $\mathrm{H}$ as the control class. In the experimental class, the learning process was conducted using Realistic Mathematics Education (RME) while in the control class, the learning process was conducted using theexpository learning method. The data obtained were in the form of test data (post-test) of mathematical analogical abilities, questionnaire of habits of mind, and the documentation of learning activities.

The instruments used in this had been tested for their validity, reliability, level of difficulty, and discrimination index. The data obtained in this study was first tested for its normality to determine the type of statistical analysis method, namely parametric or nonparametric. The research data obtained also passed the homogeneity testing process. The Liliefors test was used to see the data normality and the Bartlett test was used to see the homogeneity. Based on the results of both tests, the data were normally distributed and homogeneous.Then,the next step was to conduct the hypothetical test. The hypothetical test used was two-way ANOVA. 
Based on the background, the focus of the research is illustrated in three problem formulations. The first hypothetical test shows that $F_{\text {observed }}>F_{\text {critical }}$ which means that there are differences in mathematical analogical abilities between the class that was taught using Realistic Mathematics Education (RME) and class that was taught using expository learning. This hypothesis is in line with the opinion of Laurens et al. Stating that there are differences in cognitive achievement between learning using RME and learning using conventional learning. Mathematics teachers need to apply RME in class to make abstract mathematical concepts easier to understand. RME also helps teachers to simplify and realize mathematical concepts. Simplification of concepts and concept realization are part of the characteristics of RME, i.e. using contextual problems. Simplification of concepts in mathematics learning is necessary for terms of finding new knowledge that can be absorbed by students. The depiction of abstract material in mathematics is one of the inhibiting factors in the discovery of new knowledge. RME learning with its main contextual characteristics can analogize an abstract mathematical concept into a concrete analogy in a real-life description (Dominowski, 2002)

The results of the study show that there are significant differences between the class that was taught using RME learning and the class that was taught using expository learning. InRealistic Mathematic Education (RME) learning, the experimental class students werecognitively active by looking for analogies or equivalent concepts with real contexts. Through the process of turning something abstract into the concrete, there is a process of concept formalization so students can develop concepts that are more complete and varied. In the process of formalizing thinking, students are expected to be able to use or apply mathematical concepts to new fields of real-world context. This is often called the process of applied mathematization. In the process of applied mathematization, students' thinking patterns towards mathematical concepts need to be bridged with everyday experience.

Realistic Mathematics Education (RME) learning also implies the existence of patterns or steps in the use of mathematical models. In the learning process using realistic mathematics education (RME), students tend to find models or routine patterns for each non-routine problem. The students are required to be able to hide and look for mathematical models or patterns for each problem to be solved. In the process, the same problem can be solved using the same mathematical pattern or model. While learning using the expository method, the students tend to work on problems by not seeing the mathematical patterns or models, so that when given new problems that could be solved with the same mathematical pattern or model, they will be confused.

The learning steps of Realistic Mathematics Education (RME) emphasizes free production which means that the students can actively produce or develop ideas and concepts that can facilitate the absorption of mathematical concepts. Realistic Mathematics Education (RME) enables students to gradually construct their knowledge. In the free production process, students are encouraged to reflect, repeat and provide feedback on material or concepts that they think are important in building knowledge. Problem-solving procedures in real contexts that are informal strategies are ideas for developing and constructing formal mathematical knowledge. This is the virtue of the application of Realistic Mathematics Education (RME). 
The use of real-world contexts, mathematical modeling, and production and construction are important parts of the learning process of Realistic Mathematics Education (RME). It is also necessary to develop social skills. The interactive process that is shown in the classroom is a marker that interactive processes exist in Realistic Mathematics Education (RME). Explicitly, the interactive processes for classes that apply realistic mathematics education (RME) can be seen through the process of negotiation, explanation, justification, and agreement or disagreement. These interactive processes are indispensable in building new knowledge.

Mathematics learning applications usually require complex knowledge. This certainly involves the interconnection between knowledge. The Realistic Mathematic Education (RME) links the concepts and other fields. Conceptual relationships occur when theorems in mathematics are interrelated.

The second focus of this study is to look at differences in mathematical analogical abilities of students who have high, medium, low habits of mind taught using Realistic Mathematics Education Learning (RME). Based on the data analysis, it can be concluded that there are significant differences between students who have high, medium, and low habits of mind. The test results are significantly different for the experimental class and the control class. This implicitly confirms that different habits of mind show different characteristics in the learning process and results.

Through further observations, the pattern given by each characteristic of the mind is different. Students who have high habits of mind can explore more information or mathematical ideas of the problems faced. This can be seen when students with high habits of mind always weighed several choices of problem-solving in learning where as students with low habits of mind usually only solve problems in one choice of problem-solving. This will make it difficult for students to be able to find the best solution from several problems solving options. In previous research, students who were taught usingMathematical Habits of Mind strategy assisted by multimedia showed a positive attitude in the learning process and one of the causes was the tendency to explore mathematical ideas.

Habits of thinking or habits of mind in learning mathematics is a way how one can always develop mathematical ideas to solve a problem or concept of new knowledge cognitively. Solving mathematical problems will lead students to reflect on the truth of the answers in each process of thinking. Students with high habits of mind tend to solve the problem by checking the answers obtained after solving mathematical problems while the moderate and low students could not achieve the reflection stage of the answers. This will have an impact on the low learning outcomes or analogical abilities of students.

Students with high category habits of mind high solve problems by identifying the strategies to be used. Based on the existing problems, identification in choosing a solution strategy is an important factor in the success of the learning process. Mistakes in choosing a problem-solving strategy will result in failure and despair in finding solutions. Students with highhabits of mind also use the identification of problem-solving strategies as a bridge to solve problems at a broader stage or scale.

The habit of thinking or habits of mind is the awareness within oneself to be able to get used to and ask themselves questions about what they intend to do or ask themselves about the 
steps to be taken. Students with high habits of mind are enthusiastic about thinking. Questions to test one's ability or weigh right or wrong are the characteristics of the habit of thinking in solving problems. In the process of asking themselves, students are required to be able to pattern or formulate questions. This is almost the same as the identification of problem-solving since in formulating questions, the students must go through an identification stage.

Another important stage in habits of mind is constructing examples. In the stage of constructing examples, students are more likely to use mathematical analogies. This supports the mathematical analogicalabilities variable in RME learning. Reconstructing examples is certainly an informal mathematical process that becomes formal to obtain concepts or knowledge. The stages or characters in habits of mind make a very significant difference in the classification of high, medium, and low habits of mind. This is consistent with the second hypothetical test which states that there are differences between students who have high, medium, and low habits of mind toward their mathematical analogical abilities, both in the experimental class and the control class.

Based on the result of the third hypothetical test, it appears that there is no interaction between the learning factors (RME and expository) and the mathematical analogical abilities and habits of mind. Based on observations and test results, the experimental class that applied RME learning had a better mathematical analogicalability compared to the control class that applied expository learning. Each category of habits of mind has a different average score. This means that the average analogicalabilities in RME learning show that students with high habits of mind are better than students with moderate habits of mind. Likewise, students with moderate habits of mind are better than students with low habits of mind. This condition also occurs in expository learning. This shows that habits of mind and the learning approaches do not affect the students' mathematical analogical abilities.

\section{CONCLUSION AND SUGGESTION}

Based on the results of research and discussion, the following conclusions are obtained: 1) there are differences in mathematical analogical abilities between the class that was taught using Realistic Mathematics Education (RME) and class that was taught using expository learning; 2) there are differences in mathematical analogical abilities of students who have high, medium, low habits of mind taught using Realistic Mathematics Education Learning(RME); 3) there is no interaction between the use of Realistic Mathematics Education Learning(RME) on the habits of mind and students' mathematical analogical abilities.

It is suggested for other researchers to investigate the mathematical analogical abilities in other learning. The effective abilities (habits of mind) in this research still need to be studied in-depth on how they affect the learning process so that this research can be used as reference material for further research.

\section{REFERENCES}

Atika, N., \& Mz, Z. A. (2016). Pengembangan LKS Berbasis Pendekatan RME Untuk Menumbuhkembangkan Kemampuan Berpikir Kritis Matematis, 2(2), 103-110. 
Azmi, M. P. (2017). Asosiasi Antara Kemampuan Analogi Dengan Komunikasi Matematik Siswa SMP. Al-Jabar : Jurnal Pendidikan Matematika, 8(1), 91-100.

Bidari, I. (2016). Pengaruh Habits Of Mind Terhadap Kemampuan Generalisasi Matematika Siswa. Jakarta: UIN Syarif Hidayatullah Jakarta.

Dolk, M., \& Eerde, D. Van. (2013). Developing a Local Instruction Theory for Learning the Concept of Angle through Visual Field Activities and Spatial Representations. International Education Studies, 6(8), 58-70. https://doi.org/10.5539/ies.v6n8p58

Dominowski, R. . (2002). Teaching Undergraduates. New Jersey: Lawrence Erlbaum Assosiates Publishers.

Fernandes, M., Farida, F., Fitria, Y., Fauzan, A., \& Nelvyarni, N. (2018). Improvement Of Learning Outcomes In Result Using Realistic Mathematic Education Approach In Basic School. Unes Journal of Education Scienties, 2(2), 157-165.

Fitriani, N., Suryadi, D., \& Darhim, D. (2018). The Students'mathematical Abstraction Ability Through Realistic Mathematics Education With Vba-Microsoft Excel. Infinity Journal, $7(2), 123-132$.

Hidayat, R., \& Iksan, Z. H. (2015). The Effect of Realistic Mathematic Education on Students ' Conceptual Understanding of Linear Progamming. Creative Education, 6(December), 2438-2445. https://doi.org/10.4236/ce.2015.622251.

Indriani, L. F. (2018). Kemampuan Penalaran Matematis dan Habits Of Mind Siswa SMP dalam Materi Segiempat dan Segitiga. Jurnal Math Educator Nusantara, 4(2), 87-94. https://doi.org/10.29407/jmen.v4i2.11999

Masni, E. D. (2017). Asosiasi Kemampuan Pemecahan Masalah dan Mathematical Habits of Mind Siswa SMP. Jurnal Penelitian Pendidikan INSANI, 20(1).

Miliyawati, B. (2017). Reformulasi Strategi Habits Of Mind Matematis Terhadap Kemampuan Mathematical Critical Thingking Dalam Mewujudkan Generasi Emas Berkarakter. JNPM ( Jurnal Nasional Pendidikan Matematika ), 1(1), 24-42.

Nahadi, H, F., \& Farina, J. (2015). Effect Of Feedback In Formative Assessment In The Student Learning Activities On Chemical Course To The Formation Of Habits Of Mind. Jurnal Pendidikan IPA Indonesia, 4(1), 36-42.

Nurjannah, P. E. I., Hendriana, H., \& Fitrianna, A. Y. (2018). Faktor Mathematical Habits of Mind dan Kemampuan Literasi Matematis Siswa SMP di Kabupaten Bandung Barat. Jurnal Mercumatika: Jurnal Penelitian Matematika Dan Pendidikan Matematika, 2(2), $51-58$.

Nurmaulita. (2014). Pembentukan Habits Of Mind Siswa Melalui Pembelajaran Saling Temas Pada Mata Pelajaran Fisika. Jurnal Pendidikan Fisika, 3(1), 53-58.

Rahman, R., \& Maarif, S. (2014). Pengaruh penggunaan metode discovery terhadap kemampuan analogi matematis siswa SMK Al-Ikhsan Pamacarian Kabupaten Ciamis Jawa Barat. Jurnal Ilmiah Program Studi Matrmatika STKIP Siliwangi Bandung, 3(1), 
$33-58$.

Rudiono, T., Dafik, \& Wahyuningrum, E. (2015). Pengembangan Perangkat Pembelajaran Berbasis Rme Berorientasi Terciptanya Berfikir Tingkat Tinggi Materi Perbandingan Kelas VII. Pancaran, 4(1), 45-54.

Safitri, P. T. (2017). Analisis Habits Of Mind Matematis Siswa SMP Di Kota Tangerang. AKSIOMA: Jurnal Program Studi Pendidikan Matematika, 6(2), 205-217.

Sriyati, S., Rustaman, \& Zainul, A. (2010). Kontribusi Asesmen Formatif Terhadap Habits of Mind Mahasiswa Biologi. Jurnal Pengaajaran MIPA, 15(2), 77-86.

Sugiyono. (2013). Metode Penelitian Kuantitatif, Kualitatif dan $R \& D$.

Susanti, G., \& Rustam, A. (2018). The Effectiveness Of Learning Models Realistic Mathematics Education And Problem Based Learning Toward Mathematical Reasoning Skills At Students Of Junior High School. Journal of Mathematics Education, 3(1), 3339.

Zhok, A. (2016). Habit and Mind. On The Teleology of Mental Habits. Phenomenology and Mind, O(6), 90-99. 
